IN the last part of the Bulletin of the Paris Geographical Society for 1882 , Dr. J. Montano describes bis excursion into the interior and along the coast of Mindanao; Commander Gallieni gives a detailed narration of his mission to the Upper Niger and Seguu; M. Aymonier describes the result of his excursion to Central Cambodia; a paper by the late Dr. Crevaux gives the leading re:ults of his exploration of the Yary, Paron, IÇa, and Yapura; and M. Dutreuil de Rhins has a paper on the observations of the transits of Venus.

IN the new number (IO2) of the Zeitschrift of the Berlin Geo. graphical Society we have the usual annual systematic list of new works, papers, and maps in all departments of geography published during the past year, a list indispensable to geographers, and which will be found useful by students of the many departments of science related to geography. In the Verhandlungen (No. I, for 1883) Prof. Foerster has a paper on the expeditions for the observation of the recent transit of Venus, and Prof. Brauns a paper on the Island of Yezo. Interesting news from the various German expeditions in Africa will be found in Heft 4 of Band iii. of the Mittheilungen of the German African Society, including a detailed account of Dr. Wissmann's journey across the continent, to which we referred last week. There are four letters from Herr Flegel on the progress of his Niger explorations, and several communications of great importance from the party stationed at Gonda, in East Africa, who are accumulating material of great value. They were arranging for a visit to Lake Moero according to the latest intelligence.

IN a paper on the Gulf Stream in the Bulletin of the American Geographical Society (No. ii. 1882), Commander Bartlett gives some of the results of the examination of that current by the party in the Blake in the summer of $188 \mathrm{r}$.

THE principal paper in the February number of the Bollettino of the Italian Geographical Society is a narrative, with illustrations, by Lieut. Bove, of his mission to South America.

\section{THE OPENING OF THE FINSBURY TECHNICAL COLLEGE}

$W^{E}$ bave already given in our issue of February $I$ (p. $3 \mathrm{I} 8$ ) a brief outline of the curriculum of study to be pursued a the Finsbury Technical College, in our review of the programme of instruction recently published. The new college was opened on Monday, February I 9 , with an address by Mr. Philip Magnus, the Principal of the College, and Director of the Institute. The address was delivered in the hall of the Cowper Street School, none of the lecture-rooms of the new college being large enough for the purpose. There were present about 1200 persons, chiefly artisans. Sir Frederick Bramwell occupied the chair, and among those on the platform were Sir Sydney Waterlow, Dr. Siemens, Professors Roscoe, Abel, Carey Foster, Adams, Ayrton, Huntington, Armstrong, and Perry, Dr. Gladstone, Mr. H. T. Wood, Mr. J. G. Fitch, Mr. Swire Smith, Mr. Matthey, Mr. Owen Roberts, Mr. John Watney.

$\mathrm{Mr}$. Magnus commenced by indicating some of the incorrect ideas still prevalent on the subject of technical education. $\mathrm{He}$ considered that any definition ought to be expressed in very wide terms, so as to be referable to the different kinds of training to which the term technical education applies. He himself proposed to call that education, training, or instruction technical which had a direct reference to the career of the student who received it. Thus considered, technical education was no new thing, except in its reference to careers called into existence by recent developments of science. It was because the system of education to which we had been accustomed was no longer the best preparation for actual work, and not because no relation hitherto existed between the boy's training and the man's career that such colleges were needed. The necessity of technical education he attributed to the invention of the steam engine and the breaking-up of the apprenticeship system, and the tide which was pushing it forward would not subside until it had influenced the educational institutions of the country from the primary scho⿰l to the university. The Council had been guided by the desire to supplement, and not to duplicate, existing educational machinery. The college consisted really of a day school for pupils entering between the uges of fourteen and seventeen, and an evening school for apprentices, workmen, \&c. The former would give preparatory training to students for practical work in the factory or engineer's shop, and the evening department was intended to belp those already at work to understand the principles underlying processes they saw exemplified in their daily work. The college was therefore a technical school of the third grade, and whilst the majority of the pupils would complete within it their instruction, some would proceed to the technical high school or central institution in eoturse of erection at South Kensington. The college might claim to represent a new grade of school. It was not an institution in which any particular trade would be taught, except it were some art industry, nor would it teach the excellence, precision, and rapidity of execution which could only be acquired in the workshop or factory, where, under the severe strain of competition, salable goods were being manufactured. Proceeding to indicate the course of instruction to be given, Mr. Magnus explained that on entering the institution, the student would generally declare whether he wished to be trained as a mechanical engineer, an electrical engineer, or with a view to some branch of chemical industry, or whether he wished to study applied art, and the subjects would be taught with special reference to the career of the student. The teacher would keep steadily in view the purpose to which the student would apply his knowledge. The work would be essentially practical, ard more would be done in the labora. tory than in the lecture-room, the lectures forming rather a commentary on the practical work than the practical work an illus. tration of the teaching of the lecture-room. The main purpose was not to turn out scientists, but to explain to those preparing for industrial work the principles that had a direct bearing on their occupation, so that they might be able to trace back the principles they saw to their causes, and thus substitute scientific method for mere rule of thumb. Of the four departments of the College-electrical engineering, mechanical engineering, chemistry, and applied art-that of electrical engineering pro. mised to be the most attractive to students. But there was an intimate connection between the different branches of science not to be lost sight of in the training of a student in any one department. In the course of his remarks on the evening school and the curricula arranged for artisans engaged in various industries, Mr. Magnus referred very pointedly to the narrow view which adult workmen generally take of their own educational requirements. He impressed upon this class of students the necessity of acquainting themselves with branches of industry cognate to their own, and suggested that one of the objects of technical education was to correct the cramping and narrowing influences of extreme division of labour. He referred to a fact told him by a medical friend, that a student refused to dissect the abdominal cavity because, as a surgeon, he intended to occupy himself exclusively with diseases of the eye, and stated that this view of technical instruction needed to be strenuously resisted. He also insisted very strongly upon the importance of artisan students gaining a knowledge of the principles of science, as helping them to deal with unexpected and exceptional cases of difficulty certain to arise in their ordinary work. Mr. Magnus referred at some length to the methods of teaching to be adopted in the college, showing that there was no real opposition, as sometimes stated, between technical instruction, properly understood, and mental culture - that science might be so taught as to yield mental discipline, and yet at the same time have a direct reference to the career or occupation of the student. Mr. Magnus further explained the exact position which the Finsbury Technical College is intended to occupy in the Institute's general scheme of technical education. He illustrated this part of his address by a diagram showing the Bavarian school system, which he said was pronounced by many educational authorities to be the best in Germany, and the technical part of which was in many respects similar to the series of schools which the Institute is engaged in establishing. Mr. Magnus attached great importance to the Central Institution, now being erected in South Kensington, as crowning the educa. tional ladder which pupils from the primary schools should have the opportunity of ascending, and as influencing, in the same way as the Universities at present influence, the entire system of education pursued in the series of schools leading up to them. The speaker did not omit to refer to the Applied Art Department which has recently been added to the College, and in which the instruction he said would be specialised according to the particular occupation of the student. In conclusion $\mathrm{Mr}$. Magnus hoped the college would do much to wipe away the reproach of the neglect of technical education under which the country had hitherto lain compared with other countries. On 
the motion of Dr. Siemens, seconded by Prof. Abel, Mr. Magnus was thanked for his address. In seconding a vote of thanks to the Chairman, Alderman Sir Sydney Waterlow said their success was attributable to the generous aid of the Livery Companies, and he appealed to them to render permanent those grants hitherto given at their pleasure.

\section{SCIENTIFIC SERIALS}

The Fournal of Anatomy and Physiology, vol. xvii. Part 2, January, 1883 , contains :- On a method for the estimation of urea in the blood, Part I, by Dr. J. B. Haycraft.-On the homologies of the long flexor-muscles of the feet of Mammalia, with remarks on the value of their leading modifications in classification, by Dr. G. E. Dobson (Plates 4-6). - On obliterative endarteritis and the inflammatory changes in the coats of the small vessels, by Dr. R. Saundby (PI. 7). - The presence of a tympanum in the genus Raia, by G. B. Howes (Pl. 8). - The ligamentum teres, by J. B. Sutton (Pl. 8).Fibrinous coagula in the left ventricle, by Dr. A. M'Aldowie (Pl. 9).-A simple method of demonstrating the nerves of the epiglottis; the trachealis muscle of man and animals; the sulphocyanides of ammonium and potassium as histological reagents, by Dr. Wm. Stirling.-A new theory as to the functions of the semicircular canals, by Dr. P. M'Bride.-Some points on the myology of the common pigeon, by W. A. Haswell, M.A.-The action of saline cathartics, by Dr. M. Hay (Pl. IO).-Some variations in the bones of the human carpus; a first dorsal vertebra with a foramen at the root of the transverse process, by Prof. W. 'Turner, M. B.-Multiple renal arteries, by Dr. Macalister.-Division of the scaphoid bone of the carpus, with notes on other varieties of the carpal bones, by Dr. R. J. Anderson.

Fournal of the Royal Microscopical Society, December, 1882, contains :-On some organisms found in the excrements of the domestic goat and the goose, by Dr. R. L. Maddox (1 1. 7).On a further improvement in the Groves-Williams ether-freezing microtome, by J. W. Groves.-Summary of current researches relating to zoology and botany (principally Invertebrata and Cryptogamia), microscopy, \&c., includirg original communications from Fellows and others.-The proceedings of the Society.

February, 1883, contains:-Observations on the anatomy of the Oribatiri, by Dr. A. D. Michel (plates I and 2), -On a minute form of parasitical Protophyte, by G. F. Dowdeswell, M.A.-On the use of incandescence lamps, as accessories to the microscope, by H. C. Stearn, with figure-and the usual summary of current researches relating to botany and zoology.

Revue internationale des Sciences, December, 15, 1882, contains :-On the Nofoures of New Guinea, by Élie Reclas.-On movements and sensibility in plants (finis), by J. L. de Lanessan. $\rightarrow$ Reviews. - Notices of learned Societies: the Academy of Sciences, Paris; the Academy of Sciences, Amsterdam.

January I 5,1883 , contains :-On the localisation of the cerebral functions in the cerebral hemispheres in man and animals, by Julius Nathan.-On the development of colours in flowers, by $\mathrm{H}$. Müller.-On cell-division or cytodieresis, by L. F. Henneguy. - On the vaginal stopper in rodents, by Dr. Lataste.On the adulterations in provisions in Paris, by M. Egasse.

Zeitschrift für wissenschaftliche Zoologie, Bd. 37, Heft 4, December 22, 1882, contains :- On the Coelenterata of the South Sea, No. 1.-On Cyanea aunaskala, nov. sp., by Dr. R. v. Lendenfeld, of Melbourne (Plates 27 to $33 ; \mathrm{Pl} .27$, a coloured representation of the new species).-Contribution to the anatomy, developmental history, and general biology of Trombidium fuliginosum, Herm., by $\mathrm{H}$. Henking (Plates 34-36).-On some facts in the life-history of freshwater polyps, and on a new form of Hydra viridis, by Wm. Marshall, of Leipsig (Pl. 37).- Supplementary remarks on Dino, hilus, by Dr. E. Korschelt.

\section{SOCIETIES AND ACADEMIES LONDON}

Royal Society, February 22.- "On the Effects of Temperature on the Electromotive Force and Resistance of Batterie:," by W. H. Preece, F.R.S.

That heat has considerable influence on the condition of galvanic elements is well known, and it has been investigated by $\mathrm{De}$ la Rive, Faraday, Daniell, and many others. Some attribute the result to increased chemical affinity, and others to increased conductivity of the liquid, but no one has eliminated the effect on electromotive force from that on internal resistance with the view of expressing each in definite measurement. This the author has done. Special apparatus was made, so as to vary the temperature, and a very careful series of experiments were made upon Daniell, Leclanché, and bichromate of potash cells, measuring the electromotive force and resistance at each change of temperature in rising and falling between $0^{\circ}$ and $100^{\circ} \mathrm{C}$. The results are tabulated and plotted out as diagrams.

The conclusions are (I) that the E.M.F. is not materially affected by changes of temperature; (2) that the internal resistance is affected very materially according to a fixed law that apparently varies with every cell. A Daniell's cell at $100^{\circ} \mathrm{C}$. has only one-third the resistance it his at $0^{\circ} \mathrm{C}$. Between $10^{\circ}$ and $20^{\circ} \mathrm{C}$. it falls one half. Bichromate and Leclanché cells, though much reduced, are not reduced to the same extent ; (3) when a liquid is warmed up, its resistance at the same temperature in cooling is greater than when it was being warmed up, and it takes a very long time (fifty hours) to recover its normal condition.

Chemical Society, February 15.-Dr. Gilbert, president, in the chair.-It was announced that a ballot for the election of Fellows would take place at the next meeting (March 1).-The following proposed changes in the list of officers were also announced:-Prof. G. D. Liveing and Dr. A. Voelcker as vice-presidents instead of Professors J. Dewar and A. V. Harcourt ; Prof. Dittmar, Dr. W. R, E. Hodgkinson, Messrs. P. 1). Howard, and R. Meldola as members of Council instead of Dr. T. E. Thor pe, and Messrs. F. D. Brown, J. M. Thomson, and $\mathrm{W}$. Thorp.-The following papers were read:-On some derivatives of diphenylene ketone oxide, by A. G. Perkin. During the preparation of this substance from salicylic acid and acetic anhydride, a body was noticed which was separated out as transparent, satiny plates containing $75^{\circ} 2$ per cent. carbon, and 4 per cent. hydrogen. The author has also investigated the action of nitric acid, of bromine, and of sulphuric acid on the above substance. -On $\alpha$-ethyl valerolacton, $\alpha$-ethyl $\beta$-methyl valerolacton, and on a remarkable decomposition of $\beta$-ethyl aceto-succinic ether, by S. Young.

Anthropological Institute, February 13.-Prof. W. H. Flower, F.R.S., president, in the chair.-Mr. Colquhoun read a paper on the aboriginal and other tribes of Yünnan and the Shan country. Mr. Colquhoun first dwelt upon the races of the South China borderlands. Between Canton and Nan-ning (one of the important towns on the Si-Kiang in Kwang-si), the inhabitants met with were pure Chinese. West of that to the Yünnan frontier, a mixed population on the river and aboriginal tribes in the interior were found. Throughout Yuinnan the chief population consisted of Shans disguised under a great variety of tribal names. Lo-lo and Miao-tzŭ aborigines were met with, as well as Thibetans under the name of Kutsung. On the west side of Yuinnan Mahomedans are numerous, presumably the remains of the armies of Ginghis Kban. The costumes are most varied and picturesque, and the Shans and all the aboriginal people were kind, frank, and hospitable, and in these respects and in their feet being uncrushed offer a great contrast to the Chinese. Besides the tribes met with, Mr. Colquhoun pointed out that there were in the north and northwest Yünnan, as well as in Ssŭ-chuan, four divisions, namely Li-ssŭ, Moro, Sifan, and Mantzŭ. A great similarity of language exists between the Lo-lo, Li-ssui, Sifan, and Burmese. The large area over which the Shan population is distributed was pointed out, and the habitat of the Karens and Lawas. The paper was illustrated by part of a collection of admirable photographs and sketches made during Mr. Colquhoun's late exploration, exhibited by means of the oxhydrogen light. These form a portion of the illustrations which will appear in Mr. Colquhoun's forthcoming account of his late journey.

Geological Society, February I6th, Annual General Meeting. -J. W. Hulke, F.R.S., president, in the Chair.-The Sec. retaries read the Reports of the Council and of the Litrary and Museum Committee for the year I882. The Council expressed their regret that, owing probably to the same causes as last year, they could announce no material advance in the prosperity of the Society, although its financial position was well maintained, the balance at the close of 1882 showing an increase over that of the previous year, notwithstanding a large expenditure upon the Quarterly Journal. The total number of Fellows was diminished by one, but there was an increase of nine in the number of contributing 